\title{
DOI: 10.7596/taksad.v6i4.1142
}

Citation: Fazliev, A., Ibragimov, R., Brodovskaya, L., \& Samatova, C. (2017). Associations of Evangelical Christians-Baptists in Tatar ASSR during 1960s - 1980s. Journal of History Culture and Art Research, 6(4), 514-522. doi:http://dx.doi.org/10.7596/taksad.v6i4.1142

\section{Associations of Evangelical Christians-Baptists in Tatar ASSR during 1960s - 1980s}

\author{
Aivaz M. Fazliev ${ }^{1}$, Ruslan R. Ibragimov \\ Lyudmila N. Brodovskaya ${ }^{3}$, Chulpan H. Samatova ${ }^{4}$
}

\begin{abstract}
The relevance of the problem under study is caused by multi-confessional character of Russian society and the need of power to take into account the specific features of each confession in its religious policy. In order to understand the essential characteristics of contemporary issues in the state-confessional and inter-confessional relations the events and the processes taking place in the atheist Soviet past should be examined carefully. The purpose of the article is to study the specifics of the relationship between the authorities and associations of Evangelical Christians-Baptists during 1960s - 1980s, using the example of such a multi-confessional region as Tatarstan. The leading approach to the study of this problem was the civilizational approach, which enabled a comprehensive study of the object under study. The main results of the study are the studying of Tatar ASSR Baptist association forms and ways in the context of Soviet political and legal realities. The materials of the article can be useful in the preparation of educational literature, as well as in the practical activities of state structures implementing the policy in the spiritual sphere.
\end{abstract}

Keywords: History, Religious studies, Evangelical Christians-Baptists, The Soviet state, Soviet legislation on cults, Tatarstan.

\footnotetext{
${ }^{1}$ Kazan Federal University, Institute of International Relations, History and Oriental Studies, Kazan, Russian Federation. E-mail: aivazik@mail.ru

${ }^{2}$ Kazan Federal University, Institute of International Relations, History and Oriental Studies, Kazan, Russian Federation.

${ }^{3}$ Kazan Federal University, Institute of International Relations, History and Oriental Studies, Kazan, Russian Federation.

${ }^{4}$ Institute of Tatar encyclopedia and Regional studies of the Tatarstan Republic Academy of Sciences (Kazan), Kazan Cooperative Institute (branch) of the Russian Institute for Cooperation, Kazan, Russian Federation.
} 


\section{Introduction}

By 1917, apart from the traditional confessions of this region - Islam and Orthodoxy, other beliefs were common on the territory of the Kazan province. The following communities operated here: Catholics, Lutherans, Jews, the Old Believers of Belokrinitsky and pope free consent, various Protestant religions (Evangelical, Baptists, Pentecostals, Adventists) (Nabiev, 1997). In accordance with the legislation of Russian Empire, the above-mentioned confessions had different rights. With the adoption of "The declaration on the Rights of Peoples of Russia" by the Bolsheviks in November of 1917 all existing national and religious privileges and restrictions were abolished, each confession had equal rights to carry out their religious needs (The collection of normative acts of the Soviet state law, 1984).

During the first decade of Soviet power, its attitude toward the Baptists and Evangelical Christians was relatively mild, since the authorities used them as an instrument to combat the influence of the Russian Orthodox Church. In this regard, a significant increase of Baptists and Evangelical Christians number takes place. If by 1917 their number in the Kazan province was no more than 300 people, then over 40 of their communities operated (legally and illegally) in Tatar ASSR during 1920s (Lipakov, 2002). Anti-religious campaigns of the late 1920's - 1930's forced the association of Evangelical Christians and Baptists to act informally. Only in the conditions of relative softening of the Soviet state policy towards religion during the Great Patriotic War, Baptists and Evangelical Christians (in 1944 they merged into a single organization - the All-Union Council of Evangelical Christians and Baptists, since 1945 - All-Union Council of Evangelical Christians-Baptists (hereinafter referred to as AUCECB), as well as the representatives of other faiths, had the opportunity to register some of their associations in the state bodies. For example, in 1946 two such associations were registered in the Tatar ASSR - in the city of Kazan and Chistopol. The overwhelming majority of believers were forced to unite in illegally functioned groups and associations.

\section{Methods}

The methodological basis of the study is the civilizational approach that made it possible to identify the specifics of religious association functioning for evangelical Christian Baptists in the conditions of the social-political reality of the Soviet state during 1960s -1980s, using the example of the Tatar Autonomous Soviet Socialist Republic.

While working on the article, the author was guided by the principles of historicism and objectivity. In accordance with the first of them, the events and the processes of the past were studied and evaluated from the point of view of their emergence and development in the 
conditions of Soviet social-cultural and political realities. The principle of objectivity obliged the researcher to dissociate himself from various subjective factors that could affect the objectivity of research: political attitudes, national, religious aspirations, etc.

Special historical methods of research were used: problem-chronological, applied in the structuring and the presentation of material, which allowed us to trace the relationship of power and associations of Evangelical Christian Baptists of the republic gradually in the specified chronological framework; synchronic, which made it possible to examine the events and the processes in the life of Evangelical Christian Baptists of the Tatar ASSR in different regions that occurred in the same period; statistical, used to determine the religious activity of the Baptists of the Republic at different stages of the period under study.

\section{Discussion}

In the late 1950s - the first half of the 1960s Evangelical Christian Baptists experienced the toughening of the Soviet state policy towards religion fully, the essence of which was to increase the administrative pressure on believers and clergy, to activate massive atheist propaganda and to close the legally functioning religious associations. AUCECB leaders were forced to call on their followers to abide the Soviet legislation on cults scrupulously in order to retain its legitimacy, on the recommendation of the Council for Religious Affairs. For some part of Baptists it was unacceptable and during the early 1960s the movement of Initiatives Baptists appeared among them who defended the right to freedom of religious activities. In 1965 they created the Council of Churches of Evangelical Christians-Baptists (hereinafter CCECB) as opposed to legally prevailing AUCECB, put forward the requirements on the formation of religious organizations without official registration, and also required to cancel the decision of the All-Union Central Executive Committee and UNC RSFSR issued on April 8, 1929 "on religious associations" and the provision of the right to an unrestricted propagation of religion, declaring at the same time that the observance of Soviet legislation on cults is the deviation from the foundations of a free Baptist church. Since all these demands had the character of a pronounced dissatisfaction with the current legislation on religious cults and their disobedience, the attitude of the authorities towards this trend was defined as intolerable in the following years.

In order to strengthen the control over the activities of unregistered religious associations in general and Baptist ones in particular, as well as the desire of the state to compel the believers of this sect to comply with Soviet legislation on cults, a circular of the Council for Religious Affairs at the Council of Ministers of the USSR was issued on April 19, 1963, which 
instructed authorized persons "not to hinder the believers (mostly of sectarian associations) to use private premises for prayer meetings, that as the mass closure of houses of worship by administrative means will cause dissatisfaction among the population" (National Archives of the Republic of Tatarstan, R-873 fund, inventory 1, the case 5, sheet 328). The implementation of this directive was possible only if Baptists exclude the abovementioned actions from their activities, which are not commensurate with the Soviet legislation on cults.

After Khrushchev's removal from power, the policy of the Soviet state regarding religion was somewhat softened. However, this was not spread to the CCECB associations, which were already operating in considerable numbers during that period. In particular, in Tatar ASSR they illegally functioned in the cities of Kazan, Yelabuga, Zelenodolsk in Aksubaevsky, Bavlinsky, Kukmorsky, Cheremshansky and other regions of the republic.

Unlike the confessions recognizing the Soviet legislation on cults unconditionally, with regard to CCECB communities, as during the years of Khrushchev's assault on religion, the struggle against the activists of believers and clergy was continued, by making pressure on their close relatives. For example, in 1969, preventive conversations of the authorized Council for Religious Affairs under the USSR Council of Ministers for the Tatar ASSR, I.A. Mikhalev with an active preacher of the Kazan supporters for CCECB M.L. Yakimov, showed that the most vulnerable place in his life was the anxiety for his children, fear for the fact that his active activities in this society could harm them. In this regard, the commissioner requested the Council for Religious Affairs under the USSR Council of Ministers "... to help to use his children through the Higher Technical School (the son is the postgraduate of the Moscow Higher Technical School named after Bauman) for the correspondence with the father and meetings with him to make him break with Schismatic and develop a loyal attitude towards the Soviet power" (National Archives of the Republic of Tatarstan, fund R-873, inventory 1, case 34, sheet 18). Here, one can definitely talk about selectivity in religious policy: along with the permissibility of illegally operating religious associations existence that adhere to the legislation on cults and that do not enter into open conflict with the authorities, other measures were applied to clearly hostile religious trends and sects.

In the 1970s some representatives of local authorities began to treat religious issues in districts and cities more formally, without paying the necessary attention to information quality and objectivity improvement on the activities of religious associations. If under the conditions of Khrushchev's onslaught on religion and in this regard a frequent enough initiation of anti-religious decrees, local authorities should have been most active in their work with believers and clergy, then in the 1970s this sphere of executive committees becomes less saturated. 
Such a situation was very favorable for religious associations. Thus, in his reference on a business trip to Cheremshansky district in 1971, T. Akhmetshin, the deputy of the Council commissioner for Religious Affairs under the USSR Council of Ministers at Tatar ASSR wrote: "... apparently the religious groups of the Cheremshansky district do not feel a strict control, they work to strengthen ties, hold meetings, accept strangers, they travel for consultations themselves ..." (National Archives of the Republic of Tatarstan, fund R-873, inventory 1, case 46, sheet 37). Apparently, such trips and relevant characteristics to the local authorities were a very effective method to resume and activate the activities of the executive committees and the commissions in this direction. So, already in 1974, the work experience of the executive committee of the Cheremshansky District Council on control development over the activities of sectarian groups was considered as an exemplary one. In particular, they collected exhaustive data on the sectarians through interviews with the population and Baptists in 1971-1973. It was determined that sectarian groups were formed during the war as the result of the active preaching activity of several Baptists. By 1955, the groups of sectarians (20 - 30 men) were active in the region, the organizers of the groups had stable links with the registered Baptist Center of the USSR - AUCECB, as well as the illegal CCECB, visited the families of the sectarians from other regions of the republic, and Kazan (National Archives of the Republic of Tatarstan, fund R-873, inventory 2, file 44, sheet 1819). The mentioned above should be added by the following: a characteristic feature of the sectarian activity was the desire to spread religious views primarily among the members of their families and close relatives. In this regard, the work of the Pioneer and Komsomol organizations was of great importance in the prevention of sectarian ideas.

In the 1970s, six unregistered communities of CCECB became very active in Tatar ASSR, they had about 200 people in 1975 (Central State Archive of the Historical and Political Documentation of the Republic of Tatarstan, fund 15, inventory 8, case 1275g, sheet 11). They distributed illegal literature, created biblical schools for children and did not recognize Soviet legislation on cults openly. Among the above-mentioned communities, the most active one was the Baptist community of the Kirov district in the city of Kazan, which addressed with the letter to the 25th Congress of the CPSU. Besides, unregistered Pentecostal societies in the Soviet district and Seventh-day Adventists in Vakhitovsky district operated in the republic capital. According to the authorities on behalf of Kalaganov, the head of the propaganda and agitation department of the Tatar Regional Committee of CPSU, "... we did not succeed in the elimination of these groups activities" (Central State Archive of Historical and Political Documentation, Fund 15, inventory 8, file 1275g, sheet 13). The attention is drawn to the fact that a significant proportion of the sect members were young people and women. For example, in the Seventh-day Adventist sect (the total number of believers was 
about 40 people in the mid-1970s) organizationally formed in 1969, 80\% of its participants were women at least 32\% of them were at the age of 20 - 30 years. In connection with the above mentioned tendencies, at least 15 children and adolescents regularly attended divine services.

In the mid-1970s, young men headed the group of sectarians, the supporters of AUCECB in the Kirov district of Kazan. There were the cases of young believer's transition to this community from the official organization in Vakhitovsky district. In November of 1975, the authorities thwarted the attempt to hold an interregional conference of Baptist youth. November 8 of 1975, about 80 people - the conference delegates - came to the house of CCECB community activist of Kazan V.S. Suchkov (National Archives of the Republic of Tatarstan, fund R-873, inventory 1, case 67, sheet 86). However, the members of the voluntary national teams and the Battle Komsomol brigade did not give them the opportunity to go into the house, as in accordance with the Soviet legislation on cults such events were to be coordinated with the leadership of the republic and the Council on Religious Affairs under the USSR Council of Ministers. However, because of its undisguised hostile attitude towards the authorities, CCECB, such a resolution could not be obtained. Despite this, young Baptists, along with their children systematically visited the Mari ASSR and the Kirov region for a joint divine service with their co-religionists.

In general, with regard to CCECB, law enforcement forces were used continuously and openly. In particular, in 1974-1975 strict administrative measures with the participation of police officers were applied against the believers of the above-mentioned Kazan community CCECB. So, on January 5 of 1975, the private house (Svetlaya str., 11 in the city of Kazan), where the Baptists gathered for prayers, was visited by police and vigilantes. They took the Bible and a few manuscripts of religious content without a search warrant. On January 7, the same events and actions of the authorities were repeated, and on January 11 and 13, the guard of vigilantes was set up to counter the meetings of believers near the above-mentioned house. On October 27, 1974, the believers were visited by the representatives of authorities once again represented by the employees of the Kirov district police department - lieutenant colonel Samoilov and the second lieutenant Nefedov, as well as the representatives of the Kirov district executive committee of Kazan Kashafutdinov (National Archives of the Republic of Tatarstan, fund R-873, inventory 1, case 70, sheet 25). According to the believers, police officers and accompanying vigilantes "... grabbed the old women and pushed them into the yard, where they recorded and photographed for identification. After the end of the prayers, police and vigilantes took them out of the house of prayer with the threat, pushed them into the bus and took away for questioning" (National Archives of the Republic of 
Tatarstan, fund R-873, inventory 1 , the case 70, the sheet 24-26). The letters with the descriptions of these events were sent by believers to the General Secretary of CPSU Leonid Brezhnev, the Chairman of the USSR Supreme Council Nikolai Podgorny, the Chairman of the USSR Council of Ministers Kosygin and to a number of party and government leaders of the central and local levels. However, these letters did not have any positive consequences for the believers.

Such communities were outlawed for the state, which determined the relevant actions of the authorities in their respect. In the future, the use of extreme administrative measures also took place. Thus, on January 13 of 1978, the duty of the law and order forces resumed in the evening near the places of CCECB believer meetings, thus the prayer meeting was disrupted, and the members of the Komsomol fighting squad were taken to the headquarters of the Voluntary People's Guards, followed by protocol drawing up and there were individual conversations with some of them the purpose of finding out new personalities. On January 15, 1978, the special group of the Voluntary People's Guards of the Lenin Scientific Production Association was on duty, however, sectarians did not attend the prayer meeting (National Archives of the Republic of Tatarstan, Fund P.873, inventory 1, case 77, sheet 108-110). In this regard, the Commission for Assistance to the Executive Committee of the Kirov District Council together with the special group of the Combat Komsomol Guards conducted the work to identify new places for prayer meetings.

In addition to the use of law enforcement and fines, the party and the government bodies recommended to local authorities to use such form of influence as discussion the activities of sectarians of CCECB associations in work collectives and in the community more often. However, as the subsequent practice showed, these methods of combat were not successful.

\section{Conclusion}

The problem under study has long enjoyed the steady attention of the scientific community. The works published during the Soviet period have inevitably ideological dogmas and the stereotypes of the Soviet era (Kalinicheva, 1972, Klybanov, Mitrokhin, 1967; Lyalina, 1977; Malakhova, 1987; Mitrokhin, 1966; Filimonov, 1968). Despite this shortcoming inherent in all humanitarian works carried out in the Soviet state, the specific historical material presented in them is certainly of interest to modern researchers.

The works published during perestroika and post-soviet periods, are characterized by the understanding of the events and processes in the life of the Baptist associations of the Soviet state that took place during the period under review from the standpoint of new scientific 
approaches and the introduction of new sources into scientific circulation (Mitrokhin, 1997; Melnik, 1992; Kurilo, 1996; Licender, 2000; Plohotniuc, 1996; Knyazeva, Solovyov, 2001; and others).

Despite a significant number of works devoted to the situation of religious associations of Protestants in the Soviet state, many aspects of this problem were not studied enough at the regional level and in Tatar ASSR in particular. The novelty of the presented article is largely determined by the object of study and the source database - mainly consisting of archival documents, many of which are introduced into scientific circulation for the first time.

Thus, the schism among the evangelical Christians of the Baptists in the Soviet Union in the early 1960s gave birth to almost a unique phenomenon in the Soviet state, when a religious organization, namely CCECB, did not recognize Soviet legislation on cults openly. The experience of relations between the authorities and the community of believers from CCECB associations on the example of Tatar ASSR showed that the measures applied by the government in this regard, ranging from power actions to public condemnation, did not bring any tangible result. Such a specific relationship between the authorities and CCECB associations preserved until the end of the 1980s, until the democratization of Soviet society and the development of a fundamentally new approach by the authorities in their relations with confessions, including the Protestant ones.

\section{Acknowledgements}

The work is performed according to the Russian Government Program of Competitive Growth of Kazan Federal University.

\section{References}

Central State Archive of Historical and Political Documentation of the Republic of Tatarstan, Fund 15, inventory 8, file 1275.

Collection of normative acts on Soviet state law (1984). Moscow: Juridical Literature.

Filimonov, E. G. (1968). Baptism and Humanism. Moscow: Thought.

Kalinicheva, Z. V. (1972). The social essence of Baptism. 1917-1929. Leningrad: Science. 
Klibanov, A. I. \& Mitrokhin, L. N. (1967). Crisis phenomena in modern Baptism. Moscow: Knowledge.

Knyazeva, E. E. \& Solovieva, G. F. (2001). Lutheran churches and parishes of Russia. XVIIIXX centuries: Historical reference. St. Petersburg: Litera.

Kurilo, O. V. (1996). Essays on the history of Lutherans in Russia (XVI - XX centuries). Moscow: Lutheran Heritage Foundation.

Lipakov, E. V. (2002.) Baptism // The Tatar Encyclopedia: In 5 v. / Ch. Ed. M. Kh. Khasanov, Ed. in charge: G.S. Sabirzyanov. Kazan: Institute of the Tatar Encyclopedia of the Academy of Sciences of the Republic of Tatarstan.

Litsenberger, O. A. (2000). The Evangelical Lutheran Church and the Soviet State (19171938). Moscow: Gothic.

Lyalina, G. S. (1977). Baptism: illusions and reality. Moscow: Politizdat.

Malakhova, I. A. (1987). Modern Baptism: ideology and activity. Moscow: Knowledge.

Melnik, V. I. (1992). Youth in pentecostalism: the search for the ideal. Lviv: Svit.

Mitrokhin, L. N. (1966). Baptism. Moscow: Politizdat.

Mitrokhin, L. N. (1997). Baptism: history and modernity. St. Petersburg: RCSI.

Nabiev, R. A. (Ed.). (1997). Religious associations of the Republic of Tatarstan: Reference book. Kazan: Publishing house of Kazan State University.

National Archive of the Republic of Tatarstan, Fund R-873, inventory 1, case 5.

National Archive of the Republic of Tatarstan, Fund R-873, inventory 1, case 34.

National Archive of the Republic of Tatarstan, Fund R-873, inventory 1, case 46.

National Archive of the Republic of Tatarstan, Fund R-873, inventory 1, case 67.

National Archive of the Republic of Tatarstan, Fund R-873, inventory 1, case 70.

National Archive of the Republic of Tatarstan, Fund R-873, inventory 2, case 44.

National Archive of the Republic of Tatarstan, Fund P.873, inventory 1, case 77. 